\title{
Seroprevalence and risk factors for toxoplasmosis and neosporosis in the dog population of Ibiúna, São Paulo, Brazil
}

\section{Soroprevalência e fatores de risco para toxoplasmose e neosporose na população canina de Ibiúna, São Paulo, Brasil}

\author{
Roberta Mascolli ${ }^{1}$; Francisco Rafael Martins Soto ${ }^{2}$; Fernanda Bernardi ${ }^{1}$; Fumio \\ Honma Ito $^{3}$; Sônia Regina Pinheiros; Aline Gil Alves Guilloux ${ }^{4}$; Sérgio Santos de \\ Azevedo $^{5}$; Patricia Viana da Silva ${ }^{6}$; Solange Maria Gennari ${ }^{3}$; Annielle Regina da \\ Fonseca Fernandes ${ }^{7}$; Hilda Fátima de Jesus Pena ${ }^{3}$; Sílvio Arruda Vasconcellos ${ }^{3 *}$
}

\begin{abstract}
This study aimed to determine the prevalence of dogs seropositive for Toxoplasma gondii and Neospora caninum (Apicomplexa) and the risk factors associated with seropositivity in the dog population of Ibiúna, São Paulo, Brazil. A total of 570 animals were examined in the 48 neighborhoods of the city from September 2007 to March 2008. Serological diagnosis of T. gondii and N. caninum infections was performed using indirect immunofluorescence assay (IFA), with endpoint titers of 1:64 for $T$. gondii and 1:50 for $N$. caninum. Of the 570 animals examined, $314(55.1 \% ; 95 \% \mathrm{CI}=50.9-59.2 \%)$ were seropositive for $T$. gondii and $40(7.02 \%$; 95\% CI $=5.1-9.4 \%)$ for $N$. caninum. The variables presence of rodents $(\mathrm{OR}=2.05)$, ingestion of raw meat $(\mathrm{OR}=2.47)$, and prior sexual activity $(\mathrm{OR}=$ $1.79)$ were identified as risk factors for toxoplasmosis, whereas only prior sexual activity $(\mathrm{OR}=3.29)$ was associated with an increased risk for neosporosis. Both $T$. gondii and $N$. caninum infections were detected by IFA in the dog population of Ibiúna. Rodent control and not feeding raw meat to dogs are important to reduce the risk of infection by $T$. gondii and $N$. caninum in the region.

Key words: Epidemiology, dogs, Toxoplasma gondii, Neospora caninum, southeastern Brazil
\end{abstract}

\section{Resumo}

O objetivo do trabalho foi determinar a prevalência de animais soropositivos para Toxoplasma gondii e Neospora caninum (Apicomplexa) e determinar os fatores de risco associados à soropositividade na população canina de Ibiúna, São Paulo, Brasil. Foram examinados 570 animais distribuídos nos 48 bairros do município, no período de setembro de 2007 a março de 2008. O diagnóstico sorológico

1 Médicas Veterinárias, Prefeitura Municipal de São Paulo, São Paulo, SP, Brasil. E-mail: mascolli@uol.com.br; bernardif@uol. com.br

2 Prof., Instituto Federal de Educação, Ciência e Tecnologia de São Paulo, IFSP, Ibiúna, SP, Brasil. E-mail: chicosoto34 @gmail. com

3 Profs., Programa de Pós-Graduação em Epidemiologia Experimental Aplicada às Zoonoses, Universidade de São Paulo, USP, São Paulo, SP, Brasil. E-mail: fumio@usp.br; soniapin@usp.br; sgennari@usp.br; hfpena@usp.br; savasco@usp.br

4 Discente do Curso de Doutorado do Programa de Pós-Graduação em Epidemiologia Experimental Aplicada às Zoonoses, USP, São Paulo, SP, Brasil. E-mail: gilguilloux@hotmail.com

5 Prof., Programa de Pós-Graduação em Medicina Veterinária, Universidade Federal de Campina Grande, UFCG, Patos, PB, Brasil. E-mail: sergio@vps.fmvz.usp.br

${ }^{6}$ Prof $f^{a}$, Universidade Federal de Uberlândia, UFU, Uberlândia, MG, Brasil. E-mail: patricia@famat.ufu.br

7 Discente do Curso de Doutorado do Programa de Pós-Graduação em Medicina Veterinária, UFCG, Patos, PB, Brasil. E-mail: anni.regina@gmail.com

* Author for correspondence 
das infecções por $T$. gondii e $N$. caninum foi efetuado com a reação de imunofluorescência indireta (RIFI), adotando-se os pontos de corte de 1:64 para T. gondii e 1:50 para $N$. caninum. Dos 570 animais examinados, $314(55,1 \%$; IC 95\% =50,9\% - 59,2\%) foram soropositivos para $T$. gondii, e $40(7,02 \%$; IC $95 \%=5,1 \%-9,4 \%)$ para $N$. caninum. As variáveis presença de ratos $(\mathrm{OR}=2,05)$, ingestão de carne crua $(\mathrm{OR}=2,47)$ e atividade sexual $(\mathrm{OR}=1,79)$ foram identificadas como fatores de risco associados à toxoplasmose, e para neosporose, a variável atividade sexual $(\mathrm{OR}=3,29)$ foi identificada como fator de risco. As infecções por T. gondii N. caninum, detectadas pela RIFI, estão presentes na população canina de Ibiúna. O controle de roedores e a não administração de carne crua aos animais são importantes para reduzir o risco de infecção por T. gondii e $N$. caninum na região.

Palavras-chave: Epidemiologia, cães, Toxoplasma gondii, Neospora caninum, sudeste do Brasil

\section{Introduction}

The protozoan species Toxoplasma gondii and Neospora caninum (Apicomplexa) are obligate intracellular parasites that have a worldwide geographic distribution. Their life cycle is heteroxenous and the definitive hosts are mammalian carnivores: felids for $T$. gondii and dogs and some wild canid species for $N$. caninum (DUBEY, 2010).

Dogs play a major role in the life cycle of $N$. caninum, and even though they are not recognized as definitive hosts of $T$. gondii, Lindsay et al. (1997) showed their importance as mechanical disseminators of the latter by acting as sentinels for infection. Thus, dogs are an important link in the epidemiological chain of neosporosis and toxoplasmosis infections, which explains the growing interest in attempting to determine the role of these animals as sources of infection for other parasite species and to help select control measures that affect the natural cycle of the agents (ULLMANN et al., 2008).

The municipality of Ibiúna is located in southern São Paulo (SP) state, Brazil, at 2339'23" S and $47^{\circ} 13^{\prime} 21^{\prime}$ W. Ibiúna is one of the largest cities in the state in land area, covering a total area of 1093 $\mathrm{km}^{2}$, making it difficult to implement public health and dog population control measures. The average elevation of $996 \mathrm{~m}$ determines temperatures ranging from $6{ }^{\circ} \mathrm{C}$ to $27{ }^{\circ} \mathrm{C}$ and two marked seasons: cold and wet winters with temperatures ranging between $4{ }^{\circ} \mathrm{C}$ and $14{ }^{\circ} \mathrm{C}$ and summers with average temperatures between $16^{\circ} \mathrm{C}$ and $28{ }^{\circ} \mathrm{C}$ and maximum temperatures up to $35{ }^{\circ} \mathrm{C}$. Relative humidity ranges from $60 \%$ to $90 \%$ in most of the territory, and average annual rainfall is $1200 \mathrm{~mm}$ with regular rainfall, especially in the mountainous area. To date, no seroepidemiological investigation of $T$. gondii and $N$. caninum antibodies has been done in the dog population of the region. In this study, we aimed to determine the prevalence of dogs seropositive for $T$. gondii and $N$. caninum and the risk factors associated with seropositivity in dogs at Ibiúna, São Paulo, Brazil.

\section{Material and Methods}

The study was approved by the Bioethics Committee at University of São Paulo, São Paulo, Brazil, under protocol number 1295/2008.

Blood samples were randomly collected in the 48 neighborhoods of Ibiúna, which were grouped into four regions $(1,2,3$, and 4$)$ according to their land-use characteristics: region 1, consisting of mixed areas of recent urbanization without adequate infrastructure or services and rural areas composed of small farms; region 2, a predominantly rural area, composed mostly of small farms surrounded by forests; region 3, an urban area with adequate infrastructure; and region 4, with a predominance of small agricultural properties and leisure farms surrounded by forests. Sampling was conducted from September 2007 to March 2008, during which time a total of $570 \mathrm{dogs}$ were examined. The four regions had particular characteristics and possible risk factors that could have affected the occurrence of the diseases investigated. Ecosystem aspects and 
the breeding conditions of dogs were considered in the analyses. The grouping of a significant number of animals per region was determined according to their proximity. The four regions shared boundaries with other cities surrounding Ibiúna, resulting in a high diversity of animal species, both domestic and wild.

Sample size was calculated based on the dog population of the municipality, which was estimated at 16,065 animals. This estimate was based on a human population of 75,616 people in the city (IBGE, 2006). According to the World Health Organization guidelines for dog population management, most countries report a dog to man ratio between 1:6 and 1:10 (WHO, 1990; REICHMANN et al., 1999); however, based on dog population estimates from the Ibiúna Health Surveillance and Zoonoses Center, we used a 1:4 dog to man ratio (IBIÚNA, 2007). Sample size was calculated with an estimated prevalence of $1 \%$ and a 99\% significance level. Sampling was weighted in proportion to dog population size using dog population estimates of the 48 neighborhoods.

Blood samples were taken by puncture of the radial cephalic vein and kept under refrigeration until arrival at the laboratory. Serum was obtained from clotted blood after clot retraction, after which samples were centrifuged and serum was stored at $-20{ }^{\circ} \mathrm{C}$ until required for serological tests.

For the analysis of risk factors for toxoplasmosis and neosporosis in the dog population, dog owners answered a questionnaire that included information about dog gender, age, and prior sexual activity, presence of rodents in the domicile and peridomicile, contact with flooded areas, type of management, type of food, ingestion of raw meat, and whether the owner travel with the dog.
Detection of antibodies to $T$. gondii was conducted using indirect immunofluorescence assay (IFA) (CAMARGO, 1974) with RH-strain tachyzoites recovered from mice. IFA was also used for detection of antibodies to $N$. caninum following the recommendations of Dubey et al. (1988), using NC-1 strain tachyzoites grown in VERO cell culture. Sera to both agents were diluted in phosphate saline buffer (0.1 M, pH 7.2) and endpoint tittered at 1:64 for T. gondii and 1:50 for $N$. caninum. The reaction was visualized using commercial conjugated anti-dog IgG antibodies (Sigma, USA) labeled with fluorescein isothiocyanate. Samples with tachyzoites that demonstrated complete peripheral fluorescence were considered positive and subjected to serial dilutions, with the endpoint titer defined as the reciprocal of the last dilution showing a positive result.

Data from the epidemiological questionnaires were analyzed using uni- and multivariate analysis to determine possible risk factors associated with seropositivity for $T$. gondii and $N$. caninum. Animals were grouped into two groups (seropositive and seronegative) in the univariate analysis for comparison of the variables investigated. Variables with $\mathrm{p} \leq 0.2$ by the chi-square test or by Fisher's exact test were selected for multivariate analysis, using multiple logistic regression analysis (HOSMER; LEMESHOW, 2000). The significance level was set at $\mathrm{p}<0.05$, and all analyses were performed using SPSS 20.0 for Windows software.

\section{Results and Discussion}

Of the 570 animals examined, 314 (55.1\%; 95\% $\mathrm{CI}=50.9-59.2 \%)$ were seropositive for $T$. gondii (Table 1), with titers ranging from 64 to 4096. 
Table 1. Prevalence of Toxoplasma gondii and Neospora caninum in the dog population of Ibiúna, São Paulo (SP), Brazil, between September 2007 and March 2008.

\begin{tabular}{cccccccc}
\hline \multirow{2}{*}{ Region } & Total number & \multicolumn{3}{c}{ T. gondii } & \multicolumn{3}{c}{ N. caninum } \\
\cline { 2 - 7 } & of animals & $\mathbf{N}$ & Prevalence (\%) & $\mathbf{9 5 \%}$ CI (\%) & $\mathbf{N}$ & Prevalence (\%) & $\mathbf{9 5 \%}$ CI (\%) \\
\hline 1 & 165 & 86 & 52.1 & $44.1-59.9$ & 10 & 6.1 & $2.9-10.9$ \\
2 & 145 & 87 & 60 & $51.5-68.0$ & 8 & 5.5 & $2.4-10.6$ \\
3 & 149 & 76 & 51 & $42.7-59.3$ & 12 & 8.05 & $4.2-13.6$ \\
4 & 111 & 65 & 58.5 & $48.8-67.8$ & 10 & 9.01 & $4.4-15.9$ \\
Total & 570 & 314 & 55.1 & $50.9-59.2$ & 40 & 7.02 & $5.1-9.4$ \\
\hline
\end{tabular}

Prevalence by region for $T$ gondii ranged from $51 \%$ to $60 \%$. The seroprevalence of $T$. gondii in dog populations found in several serological surveys conducted in Brazil is high, and similar and even higher rates than the ones observed in this study have been reported. For instance, a prevalence of $60.7 \%$ was found by Guimarães et al. (2009) in Lavras, Minas Gerais (MG). However, prevalence rates of $21.3 \%, 23.1 \%, 20.8 \%, 22.3 \%$, and $25.4 \%$ were reported, respectively, by Souza et al. (2003) in São Paulo, SP, Bresciani et al. (2007) in Araçatuba, SP, Romanelli et al. (2007) in Guarapuava, Paraná (PR), Moura et al. (2009) in Lages and Balneário Camboriú, Santa Catarina (SC), and Silva et al. (2010) in Ubatuba, SP. Seroprevalence rates of $T$. gondii can vary greatly, because transmission is associated with habits and cultural behaviors as well as socio-economic and health conditions. Habitat is also a factor, because it plays a fundamental role in the viability of the parasite (SILVA et al., 2010).

Of the 314 dogs seropositive for T. gondii, $66.9 \%$ (210 animals) had titers ranging between 128 and 4096, whereas 33.1\% (104 animals) had titers between 16 and 64. Cañón-Franco et al. (2004) reported that most positive dogs (76.4\%) in Monte Negro, Rondônia (RO), had titers ranging from 128 to 2048. Conflicting results, in which most positive dogs had titers between 16 and 64, were found by Barbosa et al. (2003) in Salvador, Bahia (BA), Langoni et al. (2006) in Botucatu, SP, and Silva et al. (2010) in Ubatuba, SP. Low titers are indicative of chronic or early phases of infection (CAMARGO, 1975), which may indicate that most examined dogs have been exposed to the parasite and have developed an immunological response by producing specific antibodies.

Forty dogs were seropositive for $N$. caninum (prevalence: $7.02 \% ; 95 \% \mathrm{CI}=5.1-9.4 \%$ ), with titers ranging between 50 and 800 (Table 1). The prevalence by region ranged from $5.5 \%$ to $9.01 \%$. Similar prevalence rates $(<15 \%)$ were observed by Cañón-Franco et al. (2003) in Monte Negro, RO, Fernandes et al. (2004) in Uberlândia, MG, Azevedo et al. (2005) in Campina Grande, Paraíba (PB), Jesus et al. (2006) in Salvador and Lauro de Freitas, BA, and Magalhães et al. (2009) in Ilhéus, BA. Conversely, higher prevalence rates (> 35\%) were found by Gennari et al. (2002) in São Paulo, SP, and Moraes et al. (2008) in Botucatu, SP. Prevalence rates of $N$. caninum can vary greatly depending of several factors, including diagnostic technique, sample size, and type of dog population (CAÑÓN-FRANCO et al., 2003).

Of 40 dogs seropositive for neosporosis, 24 (60\%) had antibody titers between 50 and 200, while 16 had titer values between 400 and 800 . The most common titer value among these dogs was $400(35 \%, 14 / 40)$. Dubey et al. (1988) reported that antibody titers greater than 400 are indicative of clinical neosporosis. Azevedo et al. (2005) reported that of 24 dogs positive for neosporosis in Campina Grande, PB, 18 (75\%) had titer values between 50 and 200, and six dogs had titers between 400 and 12,800 . Similar results were reported by Fernandes et al. (2004) in Uberlândia, MG, where 
most positive dogs had a titer of $50(32.7 \%, 20 / 63)$ and the maximum titer value was $3200(2 / 63)$. In the present study, 24 dogs were positive for both $T$. gondii and $N$. caninum, which corresponds to $60 \%$ of all dogs positive for neosporosis (24/40), $7.6 \%$ of dogs positive for toxoplasmosis $(24 / 314)$, and $4.2 \%$ of all dogs examined (24/570). These results indicate that some dogs in the city may be simultaneously infected by $N$. caninum and $T$. gondii, as a consequence of the dog population of Ibiúna having been exposed to both agents (MINEO et al., 2004).
Tables 2 and 3 show the results of univariate analysis for the risk factors associated with $T$. gondii and $N$. caninum infections. In the final logistic regression models (Table 4$)$, the variables presence of rodents $(\mathrm{OR}=2.05)$, ingestion of raw meat $(\mathrm{OR}$ $=2.47)$, and prior sexual activity $(\mathrm{OR}=1.79)$ were identified as risk factors for $T$. gondii infection, whereas only prior sexual activity $(\mathrm{OR}=3.29)$ was associated with an increased risk for $N$. caninum infection.

Table 2. Univariate analysis for risk factors associated with Toxoplasma gondii (Apicomplexa) infection in the dog population of Ibiúna, São Paulo (SP), Brazil, between September 2007 and March 2008.

\begin{tabular}{|c|c|c|c|c|}
\hline Variable & Category & No. of dogs & No. of positive dogs (\%) & $\mathbf{p}$ \\
\hline \multirow[t]{2}{*}{ gender } & male & 312 & $184(59.0)$ & \\
\hline & female & 246 & $127(51.6)$ & $0.099 *$ \\
\hline \multirow[t]{3}{*}{ age (years) } & $\leq 2$ & 116 & $49(42.2)$ & \\
\hline & $2-6$ & 304 & $172(56.6)$ & \\
\hline & $>6$ & 139 & $87(62.6)$ & $0.004^{*}$ \\
\hline \multirow[t]{2}{*}{ presence of rodents } & no & 43 & $14(32.6)$ & \\
\hline & yes & 497 & $291(58.6)$ & $0.002 *$ \\
\hline \multirow[t]{2}{*}{ contact with flooded areas } & no & 465 & $258(55.5)$ & \\
\hline & yes & 71 & $44(62.0)$ & 0.369 \\
\hline \multirow[t]{3}{*}{ management } & domiciled & 255 & $114(44.7)$ & \\
\hline & semi-domiciled & 110 & $65(59.1)$ & \\
\hline & stray & 191 & $130(68.1)$ & $<0.001 *$ \\
\hline \multirow[t]{2}{*}{ feeding } & commercial food & 117 & $46(39.3)$ & \\
\hline & homemade food & 435 & $262(60.2)$ & $<0.001^{*}$ \\
\hline \multirow[t]{2}{*}{ ingestion of raw meat } & no & 222 & $89(40.1)$ & \\
\hline & yes & 329 & $217(66.0)$ & $<0.001^{*}$ \\
\hline \multirow[t]{2}{*}{ owner travels with dog } & no & 518 & $294(56.8)$ & \\
\hline & yes & 3 & $1(33.3)$ & 0.582 \\
\hline \multirow[t]{2}{*}{ prior sexual activity } & no & 201 & $88(43.8)$ & \\
\hline & yes & 339 & $212(62.5)$ & $<0.001 *$ \\
\hline
\end{tabular}

*Variables selected for multivariate analysis $(\mathrm{p} \leq 0.2)$. 
The presence of rodents as a risk factor for usually hunt and prey upon rodents and birds, toxoplasmosis was expected, because rodents and some individuals may ingest tissue cysts and birds have been described as important intermediate become infected. Similar results were observed by hosts that harbor tissue cysts of T. gondii in their Romanelli et al. (2007) in Guarapuava, PR, where bodies (DUBEY, 2010). Because cats and dogs the presence of rodents in food storage silos was an important risk factor for canine toxoplasmosis.

Table 3. Univariate analysis for risk factors associated with Neospora caninum (Apicomplexa) infection in the dog population of Ibiúna, São Paulo (SP), Brazil, between September 2007 and March 2008.

\begin{tabular}{|c|c|c|c|c|}
\hline Variable & Category & No. of dogs & $\begin{array}{l}\text { No. of positive dogs (\%) } \\
\end{array}$ & $\mathbf{P}$ \\
\hline \multirow[t]{2}{*}{ gender } & male & 312 & $31(9.9)$ & \\
\hline & female & 246 & $14(5.7)$ & $0.095^{*}$ \\
\hline \multirow[t]{3}{*}{ age (years) } & $\leq 2$ & 116 & $3(2.6)$ & \\
\hline & $2-6$ & 304 & $25(8.2)$ & \\
\hline & $>6$ & 139 & $17(12.2)$ & $0.019 *$ \\
\hline \multirow[t]{2}{*}{ presence of rodents } & no & 43 & $5(11.6)$ & \\
\hline & yes & 497 & $38(7.6)$ & 0.373 \\
\hline \multirow[t]{2}{*}{ contact with flooded areas } & no & 465 & $38(8.2)$ & \\
\hline & yes & 71 & $5(7.0)$ & 0.927 \\
\hline \multirow[t]{3}{*}{ management } & domiciled & 255 & $15(5.9)$ & \\
\hline & semi-domiciled & 110 & $11(10.0)$ & \\
\hline & stray & 191 & $16(8.4)$ & 0.342 \\
\hline \multirow[t]{2}{*}{ feeding } & commercial food & 117 & $10(8.5)$ & \\
\hline & homemade food & 435 & $33(7.6)$ & 0.881 \\
\hline \multirow[t]{2}{*}{ ingestion of raw meat } & no & 222 & $15(6.8)$ & \\
\hline & yes & 329 & $27(8.2)$ & 0.642 \\
\hline \multirow[t]{2}{*}{ owner travels with dog } & no & 518 & $38(7.3)$ & \\
\hline & yes & 3 & $0(0)$ & 1.000 \\
\hline \multirow[t]{2}{*}{ prior sexual activity } & no & 201 & $7(3.5)$ & \\
\hline & yes & 339 & $36(10.6)$ & $0.005^{*}$ \\
\hline
\end{tabular}

*Variables selected for multivariate analysis $(\mathrm{p} \leq 0.2)$. 
Table 4. Risk factors associated with Toxoplasma gondii and Neospora caninum (Apicomplexa) infections in the dog population of Ibiúna, São Paulo (SP), Brazil, between September 2007 and March 2008, identified by multiple logistic regression analysis.

\begin{tabular}{lccc}
\hline Variable & Odds ratio & $\mathbf{9 5 \%}$ CI & p \\
\hline Toxoplasma gondii & & & 0.051 \\
Presence of rodents & 2.05 & $0.99-4.23$ & $<0.001$ \\
Ingestion of raw meat & 2.47 & $1.69-3.61$ & 0.003 \\
Prior sexual activity & 1.79 & $1.22-2.62$ & \\
& & & 0.005 \\
Neospora caninum & 3.29 & $1.43-7.54$ & \\
Prior sexual activity & & & \\
\hline
\end{tabular}

The ingestion of oocysts in contaminated water or tissue cysts in raw or undercooked meat is considered the main route of $T$. gondii infection. In our study, dogs that ingested raw meat had 2.47 times the risk of infection than dogs that did not have access to raw meat. Similar results that also support this association were reported by Moura et al. (2009) in Lages and Balneário Camboriú, SC, and by Silva et al. (2010) in Ubatuba, SP. In Brazil, the habit of feeding leftovers to pets is wellestablished among dog owners, especially in cities where the countryside is close to urban areas, as is the case in Ibiúna. In fact, this type of behavior favors the spread of $T$. gondii infection (SILVA et al., 2010).

Dogs that had previously mated had 1.79 and 3.29 times the risk of being infected with $T$. gondii and $N$. caninum, respectively, than dogs that had never mated. Thus, prior sexual activity can be considered a risk behavior for infection. Moreover, sexually active stray male dogs travel long distances, which may expose these dogs to various contaminated habitats, further increasing the risk for infection.

\section{Conclusions}

Toxoplasma gondii and N. caninum infections were detected by indirect immunofluorescence assay (IFA) in the dog population of the tourist city of Ibiúna, São Paulo, Brazil. The analysis of risk factors indicates that rodent control and not feeding raw meat to dogs are important to reduce the risk of infection by $T$. gondii and $N$. caninum in the region.

\section{References}

AZEVEDO S. S.; BATISTAC. S. A.; VASCONCELLOS, S. A.; AGUIAR, D. M.; RAGOZO A. M.; RODRIGUES, A. A.; ALVES, C. J.; GENNARI, S. M. Seroepidemiology of Toxoplasma gondii and Neospora caninum in dogs from the state of Paraiba, Northeast region of Brazil. Research in Veterinary Science, Oxford, v. 79, n. 1, p. 51-56, 2005.

BARBOSA, M. V. F.; GUIMARÃES, J. E.; ALMEIDA, M. A. O.; GONDIM, L. F. P.; REGIS, G. B. Frequência de anticorpos IgG anti-Toxoplasma gondii em soros de cães errantes da cidade de Salvador-Bahia, Brasil. Brazilian Journal of Veterinary Research and. Animal Science, São Paulo, v. 40, n. 6, p. 457-465, 2003.

BRESCIANI, K. D. S.; COSTA, A. J.; NUNES, C. M. A.; SERRANO, A. C. M.; MOURA, A. B.; STOBBE, N. S.; PERRI, S. H. V.; DIAS, R. A.; GENNARI, S. M. Ocorrência de anticorpos contra Neospora caninum e Toxoplasma gondii e estudo de fatores de risco em cães de Araçatuba - SP. ARS Veterinaria, Jaboticabal, v. 23, n. 1, p. 40-46, 2007.

CAMARGO, M. E. Diagnóstico sorológico da toxoplasmose na gravidez. Revista da Associação Médica Brasileira, São Paulo, v. 21, n. 11, p. 341-346, 1975.

. Introdução às técnicas de imunofluorescência. Revista Brasileira de Patologia Clínica, São Paulo, v. 10, n. 4, p. 143-171, 1974. 
CAÑÓN-FRANCO, W. A.; BERGAMASCHI, D. P.; LABRUNA, M. B.; CAMARGO, L. M. A.; SOUZA, S. L. P.; SILVA, J. C. R.; PINTER, A.; DUBEY, J. P.; GENNARI, S. M. Prevalence of antibodies to Neospora caninum in dogs from Amazon, Brazil. Veterinary Parasitology, Amsterdam, v. 115, n. 1, p. 71-74, 2003.

CAÑÓN-FRANCO, W. A.; BERGAMASCHI, D. P.; LABRUNA, M. B.; CAMARGO, L. M.; SILVA, J. C.; PINTER, A.; GENNARI, S. M. Occurrence of antiToxoplasma gondii antibodies in dogs in the urban area of Monte Negro, Rondônia, Brazil. Veterinary Research Communications, Amsterdam, v. 28, n. 2, p. 113-118, 2004.

DUBEY, J. P. Toxoplasmosis of animals and humans. 2. ed. Boca Raton: CRC Press, 2010. 313 p.

DUBEY, J. P.; CARPENTER, J. L.; SPEER, C. A.; TOPPER, M. J.; UGGLA, A. Newly recognized fatal protozoan disease of dogs. Journal of the American Veterinary Medical Association, New York, v. 192, n. 9, p. 1269-1285, 1988.

FERNANDES, B. C. T. M.; GENNARI, S. M.; SOUZA, S. L. P.; CARVALHO, J. M.; OLIVEIRA, W. G.; CURY, M. C. Prevalence of anti-Neospora caninum antibodies in dogs from urban, periurban and rural areas of the city of Uberlândia, Minas Gerais, Brazil. Veterinary Parasitology, London, v. 123, n. 1-2, p. 33-40, 2004.

GENNARI, S. M.; YAI, L. E. O.; DÁURIA, S. N. R.; CARDOSO, S. M.; KWOK, O. C.; JENKINS, M. C.; DUBEY, J. P. Occurrence of Neospora caninum antibodies in sera from dogs of the city of São Paulo, Brazil. Veterinary Parasitology, London, v. 106, n. 1-2, p. 177-179, 2002.

GUIMARÃES,A. M.; ROCHA, C. M. B. M.; OLIVEIRA, T. M. F. S.; ROSADO, I. R.; MORAIS, L. G.; SANTOS, R. R. D. Fatores associados à soropositividade para Babesia, Toxoplasma, Neospora e Leishmaniaem cães atendidos em nove clínicas veterinárias do município de Lavras, MG. Revista Brasileira de Parasitologia Veterinária, Jaboticabal, v. 18, p. 49-53, 2009. Suplemento 1.

HOSMER, D. W.; LEMESHOW, S. Applied logistic regression. New York: John Wiley \& Sons, 2000. 375p.

INSTITUTO BRASILEIRO DE GEOGRAFIA E ESTATÍSTICA - IBGE. Pesquisa nacional por amostra de domicílios. Rio de Janeiro: IBGE, 2006. v. 25, 125 p.

IBIÚNA. Centro de vigilância sanitária e controle de zoonoses. Município de Ibiúna. 2007. Disponível em: $<\mathrm{http} / / /$ www.cevisa.ibiuna.sp.gov.br/>. Acesso em: 20 mar. 2014.
JESUS, E. E. V.; SANTOS, P. O. M.; BARBOSA, M. V. F.; PINHEIRO, A. M.; GONDIM, L. F. P.; GUIMARÃES, J. E.; ALMEIDA, M. A. O. Frequência de anticorpos antiNeospora caninum em cães nos municípios de Salvador e Lauro de Freitas, Estado da Bahia - Brasil. Brazilian Journal of Veterinary Research and Animal Science, São Paulo, v. 43, n. 1, p. 5-10, 2006.

LANGONI, H.; MODOLO, J. R.; PEZERICO, S. B.; SILVA, R. C.; CASTRO, A. P. B.; SILVA, A. V. da; PADOVANI, C. R. Serological profile of antiToxoplasma gondii antibodies in apparently healthy dogs of the city of Botucatu, São Paulo State, Brazil. Journal of Venomous Animals and Toxins including Tropical Diseases, Botucatu, v. 12, n. 1, p. 142-148, 2006.

LINDSAY, D. S.; DUBEY, J. P.; DUNCAN, R. B. Confirmation that the dog is a definitive host for Neospora caninum. Veterinary Parasitology, London, v. 82, n. 4, p. 327-333, 1997.

MAGALHÃES, V. C. S.; SICUPIRA, P. M. L.; GONDIM, L. F. P.; MUNHOZ, A. D. Frequência de anticorpos contra Neospora caninum em cães do município de Ilhéus, Bahia. Ciência Animal Brasileira, Goiânia, v. 10, n. 1, p. 306-311, 2009.

MINEO, T. W. P.; SILVA, D. A. O.; NÄSLUND, K.; BJÖRKMAN, C.; UGGLA, A.; MINEO, J. R. Toxoplasma gondii and Neospora caninum serological status of different canine populations from Uberlândia, Minas Gerais. Arquivo Brasileiro de Medicina Veterinária e Zootecnia, Belo Horizonte, v. 56, n. 3, p. 414-417, 2004.

MORAES, C. C. G.; MEGID, J.; PITUCO, E. M.; OKUDA, L. H.; FAVA, C. D.; STEFANO, E.; CROCCI, A. J. Ocorrência de anticorpos anti-Neospora caninum em cães da microrregião da Serra de Botucatu, Estado de São Paulo, Brasil. Revista Brasileira de Parasitologia Veterinária, Jaboticabal, v. 17, n. 1, p. 1-6, 2008.

MOURA, A. B.; SOUZA, A. P.; SARTOR, A. A.; BELLATO, V.; TEIXEIRA, E. B.; PISETTA, G. M.; HEUSSER JUNIOR, A. Ocorrência de anticorpos e fatores de risco para infecção por Toxoplasma gondii em cães nas cidades de Lages e Balneário Camboriú, Santa Catarina, Brasil. Revista Brasileira de Parasitologia Veterinária, Jaboticabal, v. 18, n. 3, p. 52-56, 2009.

REICHMANN, M. L. A. B.; PINTO, H. B. F.; NUNES, V. P. Vacinação contra raiva de cães e gatos. São Paulo: Instituto Pasteur, 1999. 32 p.

ROMANELLI, P. R.; FREIRE, R. L.; VIDOTTO, O.; MARANA, E. R.; OGAWA, L.; DE PAULA, V. S.; GARCIA, J. L.; NAVARRO, I. T. Prevalence of Neospora caninum and Toxoplasma gondii in sheep and dogs from Guarapuava farms, Paraná State, Brazil. Research in Veterinary Science, Oxford, v. 82, n. 2, p. 202-207, 2007. 
SILVA, R. C.; SOUZA, L. C.; LANGONI, H.; TANAKA, E. M.; LIMA, V. Y.; SILVA, A. V. Risk factors and presence of antibodies to Toxoplasma gondii in dogs from the coast of São Paulo State, Brazil. Pesquisa Veterinária Brasileira, Seropédica, v. 30, n. 2, p. 161-166, 2010.

SOUZA, S. L. P.; GENNARI, S. M.; YAI, L. E. O.; D'AURIA, S. R. N.; CARDOSO, S. M. S.; GUIMARÃES JÚNIOR, J. S.; DUBEY, J. P. Occurrence of Toxoplasma gondii antibodies in sera from dogs of the urban and rural areas from Brazil. Revista Brasileira de Parasitologia Veterinária, Jaboticabal, v. 12, n. 1, p. 1-3, 2003.
ULLMANN, L. S.; GUIMARÃES, F. F.; FORNAZARI, F.; TOMÉ, R. O.; CAMOSSI, L. G.; GRECA, H.; SILVA, R. C.; MENOZZI, B. D.; LANGONI, H. Ações de vigilância continuada, papel do cão como sentinela para toxoplasmose. Revista Brasileira de Parasitologia Veterinária, Jaboticabal, v. 17, n. 1, p. 345-347, 2008.

WORLD HEALTH ORGANIZATION - WHO. Guidelines for dog population management. Geneva: World Health Organization, 1990. 116 p. 
